\title{
ESTUDIOS SOBRE PERONISMOS PROVINCIALES: UN CAMBIO EN EL RÉGIMEN DE PREGUNTAS
}

\author{
CÉSAR TCACH
}

Universidad Nacional de Córdoba / CONICET

Cuando en 2003 publicamos con Darío Macor la primera edición del tomo I de La invención del peronismo en el interior del país, el título del libro, cuyo segundo volumen está ahora a punto de aparecer, causó cierto desasosiego ${ }^{1}$.

No tanto por la palabra «invención». Ya en 1998, Federico Neiburg había publicado su libro Los intelectuales y la invención del peronismo, obra en la que remitía a la idea de una construcción social, al papel que los intelectuales habían tenido en esa forja, y se situaba en las antípodas de los argumentos esencialistas que buscaban encerrar sus virtudes y defectos, en una naturaleza determinada. Esta visión no substancialista, que expresaba en el título de su libro, puede concebirse como el revés de la obra de Carlos Fayt, publicada en 1967, La naturaleza del peronismo ${ }^{2}$.

Neiburg, ponía énfasis en las figuras intelectuales que participaron en la construcción del peronismo; a una invención en que los protagonistas principales no eran sectores populares sino figuras pertenecientes a otros espacios sociales que hicieron apuestas sobre él. Remitía, en consecuencia, al campo intelectual, a los debates intelectuales. Más recientemente, Estela Spinelli en su último libro, De antiperonistas a peronistas revolucionarios, hace referencia al "peronismo re-inventado" por las clases medias en un contexto de radicalización política durante la década del '60, y particularmente, a partir de la «Revolución Argentina» ${ }^{3}$.

Lo novedoso, en todo caso, de hablar de La invención del peronismo en el interior del país, es que suponía afirmar que no hubo una única invención, sino distintas invenciones cuya riqueza y matices no se podían reducir a las construidas en las áreas centrales, y que tampoco se limitaban al universo intelectual.

${ }^{1}$ Darío Macor y César Tcach (comps.), La invención del peronismo en el interior del país, Santa Fe, Ediciones UNL, 2003.

2 Federico Neiburg, Los intelectuales y la invención del peronismo, Buenos Aires, Alianza Editorial, 1998; Carlos Fayt, La naturaleza del peronismo, Buenos Aires, Viracocha, 1967.

${ }^{3}$ María Estela Spinelli, De antiperonistas a peronistas revolucionarios, Buenos Aires, Sudamericana, 2013. 
La expresión «el interior del país» también despertó mayor inquietud ¿Por qué?, ¿qué es el interior del país?, ¿una categoría analítica, un concepto teórico, una metáfora del país ignorado? En nuestra intención, ninguna de las tres cosas. Supone, diría yo, una estrategia de análisis que partiendo del reconocimiento de realidades diversas, no se limitaba a repetir las mismas preguntas, sino que suponía una innovación en el régimen de preguntas. Pongo un ejemplo sencillo para entendernos: era inconducente preguntarse cómo habían contribuido los migrantes internos o migrantes recientes (en el sentido de Peter Smith) a la formación del peronismo, porque, sencillamente, no había migrantes internos que analizar. Hablar entre comillas del interior del país, habilitaba una innovación en el conjunto de interrogantes asociados al objeto de análisis. Abría nuevos interrogantes, modificaba el régimen de preguntas.

Ya en la década de los setenta, emergieron esbozos y filones de pensamiento que se orientaban en esa dirección. En 1973, Gino Germani en un artículo publicado en Desarrollo Económico, «El surgimiento del peronismo: el rol de los obreros y de los migrantes internos», distinguía entre centro y periferia, incluyendo en el centro a Buenos Aires y el Litoral. En 1974, Torcuato Di Tella en su libro Clases sociales y estructuras políticas, aludía en un pie de página al apoyo de las clases medias al peronismo en las provincias más atrasadas desde el punto de vista de su desarrollo económico social, y desde esta perspectiva sostenía que en esas provincias el peronismo tenía un parecido de familia con el Aprismo en Perú, fundado por Haya de la Torre.

Poco después, en 1975, Tulio Halperin Donghi, también en la revista Desarrollo Económico, advertía dos defectos en las observaciones de Germani: cierta imprecisión geográfica en la distinción entre «centro» y "periferia» y cierta rigidez en la contraposición entre lo «tradicional» y lo «moderno». Varias décadas después es posible constatar -a partir de los trabajos específicos de numerosos investigadores- la validez de la advertencia. No es lo mismo Jujuy (en la obra de Adriana Kindgard), que Mar del Plata (en los textos de Nicolás Quiroga) o Corrientes (en los trabajos de María del Mar Solis Carnicer) ${ }^{4}$.

\footnotetext{
${ }^{4}$ Gino Germani, «El surgimiento del peronismo: el rol de los obreros y de los migrantes internos», en: Desarrollo Económico, № 51, IDES, 1973; Torcuato Di Tella, Clases sociales y estructuras políticas, Buenos Aires, Paidós, 1974; Tulio Halperin Donghi, «Algunas observaciones sobre Germani, el surgimiento del peronismo y los migrantes internos», en: Desarrollo Económico, №56, IDES, 1975; Adriana Kindgard, Alianzas y enfrentamientos en los orígenes del peronismo jujeño, Universidad Nacional de Jujuy, 2001; Nicolás Quiroga, La dimensión local del Partido Peronista. Las unidades básicas durante el primer peronismo. Mar del Plata (1946-1955), tesis doctoral, Universidad Nacional de Mar del Plata, 2010; María del Mar Solís Carnicer, «El peronismo en la provincia de Corrientes: orígenes,
} 
En la década de los setenta y comienzos de los ochenta, observaciones parciales, intuiciones, esbozos, filones de pensamiento comenzaban a habilitar una innovación en el régimen de preguntas que tenía que ver con el clivaje regional/provincial/nacional. Esa innovación no era provinciana ni localista pero abría la puerta a nuevos problemas -ocultos o minimizados en los relatos macro- de los que la historiografía debía hacerse cargo si quería avanzar hacia interpretaciones más integrales de la historia argentina.

Estas nuevas líneas de investigación tenían un carácter conflictivo con dos tipos de miradas que fueron durante largo tiempo naturalizadas: 1) las miradas desde el centro; 2) las miradas de parroquia.

Las primeras se apoyan en un supuesto teórico implícito, el del «epifenómeno»: reducen a epifenómeno o «reflejo», lo ocurrido fuera de las áreas centrales, básicamente, Buenos Aires; impiden ver -utilizando una metáfora de Daniel Lvovich para el caso del peronismo neuquino- «más allá de Plaza de Mayo»; no niegan lo singular, pero lo singular es un equivalente funcional de lo pintoresco o de lo folklórico. A contraviento de esta concepción, se sitúan también los trabajos de historiadores, como los de Orietta Favaro o Susana Bandieri, orientados al reconocimiento de la relevancia histórica de las diversidades regionales y provinciales 5 .

Las segundas rinden culto a lo «local», parten de un supuesto implícito que permite evocar la frase de Tolstoi, "pinta tu pueblo y pintarás el mundo». Esta concepción se asocia a un discurso reivindicatorio de provincias postergadas y, por ende, relegadas en su importancia. Este discurso reivindicatorio opera como mecanismo de legitimación del culto a lo local. Así, se puede hablar de un «San Martín correntino» (operación historiográfica estudiada por María Silvia Leoni y Gabriela Quińonez), o de la «santiagueñidad", título del libro de Julio César Castiglione, ex director del diario El Liberal, publicado en 2012. En algunos casos, las Juntas Provinciales de Historia no fueron ajenas a esta exaltación de la singularidad ${ }^{6}$.

universo ideológico y construcción partidaria (1943-1949)», en: Darío Macor y César Tcach (comps.), La Invención del Peronismo en el interior del país, t. 2, Santa Fe, Ediciones UNL, 2013.

${ }^{5}$ Susana Bandieri, «La posibilidad operativa de la construcción histórica regional o cómo contribuir a una Historia Nacional más complejizada», en: Sandra Fernández y Gabriela Dalla Corte (comps.), Lugares para la Historia. Espacio, historia regional e historia local en los estudios contemporáneos, Rosario, Universidad Nacional de Rosario, 2001; Orietta Favaro, «Realidades contrapuestas a los estados provinciales: Ios Territorios Nacionales (1884-1955)», en: Realidad Económica, № 144 , Buenos Aires, IADE, 1996.

${ }^{6}$ María Silvia Leoni y Gabriela Quiñónez, «Combates por la memoria. La elite dirigente correntina y la invención de una tradición sanmartiniana», en: Anuario de Estudios Americanos, Sevilla, LVIII, № 1, 2001. 
Unas y otras, desde ángulos distintos, limitan la posibilidad de avanzar en una visión más integral de la historia argentina. Y ambas pueden asociarse -en mayor o menor medida según los casos- a lo que Paul Ricoeur, en su libro La memoria, la historia, el olvido, denomina la «memoria impedida», para diferenciarla de la memoria manipulada, la memoria de Estado. La memoria impedida tiene que ver con la represión -con el olvido de determinados contenidos que son necesarios para la construcción de un mito social-. Por ejemplo, al finalizar la Segunda Guerra Mundial la construcción del mito de la resistencia francesa («todos fuimos resistentes») ocultaba la complicidad de parte de la sociedad civil francesa con el ocupante alemán. Como dice Régine Robin: «Se olvida, se reprime, se pone distancia en lo más profundo, lo que molesta, se llenan los roperos de la historia de cadáveres, esperando abrirlos y encontrarlos sin poderlos reconocer ${ }^{7}$. De modo análogo, el mito de la columna vertebral en el peronismo, exigía olvidar las elites provinciales que lo hicieron posible en muchos lugares del país.

Los aportes reunidos en este dossier derivados de una mesa especial sobre «Peronismos provinciales» -que planeamos coordinar Darío y yo en el XI Congreso Nacional de Ciencia Política celebrado en Paraná en 2013 y que tuvo lugar en la gris densidad de su ausencia-, remiten a clivajes en que las intersecciones entre lo provincial y lo nacional tuvieron un rol privilegiado. Avanzar en una visión renovada de la historia argentina implica estudiar su peso en la configuración de las culturas políticas, tomando en consideración sus vasos comunicantes tanto en el terreno de las representaciones como de las prácticas políticas; imperativo que, en el ámbito de la historia reciente, se ve crecientemente complejizado, como han destacado los politólogos Ernesto Calvo y Marcelo Escobar, por el descentramiento de la política nacional hacia lo local ${ }^{8}$.

Finalmente, quiero recomendar vivamente la introducción que elaboramos con Darío Macor para el segundo tomo de La invención del peronismo en el interior del pais, y que denominamos «El oxímoron peronista en las provincias». En este prefacio polemizamos con Ernesto Laclau, cuando sostiene que el peronismo nació exaltando la figura del descamisado y concluyó rindiendo culto al mito de la comunidad organizada. En el libro, se develan los mecanismos que habilitaban y legitimaban el desplazamiento coactivo de los disidentes en los niveles dirigenciales desde un primer momento. Ambos aspectos, ambas figuras, la del descamisado y la comunidad organizada, el culto

\footnotetext{
${ }^{7}$ Régine Robin, La memoria saturada, Buenos Aires, Waldhuter, 2012, p. 37; Paul Ricoeur, La memoria, la historia, el olvido, Buenos Aires, Fondo de Cultura Económica, 2000.

${ }^{8}$ Ernesto Calvo y Marcelo Escobar, La nueva política de partidos en Argentina. Crisis política, realineamientos partidarios y reforma electoral, Buenos Aires, Prometeo, 2005.
} 
al pueblo y el culto al verticalismo jerárquico, ya estaban presentes en el modelo originario del peronismo, en su matriz fundacional. En ella, el peronismo se pensó a sí mismo, en un lugar que definía su forma de concebir y practicar la política. ¿Cuál era ese lugar? El de «una ciudadela cerrada, y en una ciudadela cerrada, toda disidencia es traición» ${ }^{9}$. Esta ubicación imaginaria del peronismo, cercado por acechantes enemigos, no significaba, por cierto, la ausencia de enemigos reales, pero al tornar ilegítima las divergencias, habilitaba el uso de mecanismos de disciplinamiento que incluían instancias de coacción y represión selectiva. Y en un sentido más amplio, conducía a afianzar en el plano estatal una concepción de la política reacia a los mecanismos de accountability, es decir a los mecanismos de control.

Finalmente, La invención del peronismo, en ese segundo tomo, permite interrogarnos por lo que el peronismo en las provincias tuvo de oxímoron: soñó con ser un partido de acero provisto de una rígida disciplina, pero en los hechos fue con frecuencia un semillero de pleitos minúsculos. No hubo Gulag que reflejase esa concepción vertical y organicista de la práctica política, pero distó de carecer de efectos de sentido. Al contrario, tuvo una incidencia clave, con una vigencia plena durante toda la vida de Perón, el gobierno de Isabel Martínez y pareció debilitarse en competencia con los nuevos aires democráticos a partir del ejercicio del voto directo en las elecciones de julio de 1988 para elegir candidato a Presidente de la nación entre Carlos Menem y Antonio Cafiero. Pero un hilo conductor que hunde sus raíces en la matriz originaria, en el parto mismo del peronismo como fenómeno político y social, hace que irrumpa muchas veces re-significada en nuestra vida política.

${ }^{9}$ Esta frase, atribuida originariamente a Agustín de Hipona (San Agustín) encuentra su evidencia empírica en numerosos ejemplos históricos. Así, por ejemplo, la guerra civil en Rusia (1918-21), o el bloqueo norteamericano a Cuba desde inicios de la década de los sesenta del siglo XX, operaban a favor de una construcción de sentido que tendía a legitimar -para hacer frente a las amenazas- modos autoritarios de hacer política. 